In: Oakley, G. (2019). Mobile technologies in children's language and literacy: Innovative pedagogy in preschool and primary education. London: Emerald.

\title{
Mobilising critical literacies: Text production in children's hands
}

\author{
Lisa Kervin, Annette Woods, Barbara Comber and Aspa Baroutsis
}

\begin{abstract}
The structures, procedures and relationships within schools both constrain and enable the ways that children and teachers can engage with the everyday 'business' of literacy learning. In schools and classrooms, the resources available to children, the spaces in which they work, and how adults interact with them, are often decided upon by others, including their teachers. In this chapter, we focus specifically on access to mobile digital resources and important spaces in the school, arguing that opportunities for children to be critical consumers and producers of text can be provided when children are afforded some control of decisions about how, where and when people, materials, tools and texts are used.

Drawing from data collected as part of a larger study of learning to write in the early years of schooling, at two different schools in different Australian states, we examine two cases of 'disruption' negotiated by children and their teachers. We explore the potential of mobile technologies in children's hands as key elements in changing the socio-spatial power relations around text production that usually hold in schools. These instances are explicit opportunities to study what is possible when young children and teachers work to change children's relationships to materials, spaces and people in productive and provocative ways. We analyse the digital texts produced and the work of teachers and children to foreground digital literacies as a way to influence what goes on in their schools.
\end{abstract}

\section{Introduction}

Children's bodies are regulated in schooling in predictable ways that subject them to constant surveillance. School timetables, classroom routines and the organisation of spaces through furniture placement, accessibility to texts, resources and other materials, mean that individuals can be located and monitored as a matter of routine. This surveillance works to do much more than just keep children safe and able to learn, as has been argued by education scholars, particularly those drawing on Foucauldian, poststructural and posthuman frames (see for example Woods \& Henderson, 2008, Comber, 2000).

From a critical literacy standpoint, we explore how teachers and children might contest traditional roles, positions and placements as they engage in learning at school. Vasquez (2014) identified the typical discourses of control that exist in artefacts of schooling - such as curriculum and testing - and the need to deliberately disrupt these in everyday classroom life. We argue that digital and smart technologies provide particular mobility affordances while 'being' a student. This also means researchers need new ways to understand the structures, procedures and relationships within schools and how these may constrain and/or enable children and teachers as they engage in literacy learning. We focus specifically on access to mobile, digital resources but also focus on spaces; particularly on occasions when children and teachers use or access spaces differently. Our argument is that opportunities for children to be critical consumers and producers of text can be provided when children are afforded some control of decisions about how, where and when people, materials, tools and texts are used and move.

International studies indicate that the regulation of children's bodies is particularly significant (eg Dixon, 2011; Kamler, Maclean, Reid \& Simpson 1994; Luke, 1992) with respect to early school literacy instruction (Dyson, 2016; Marsh, 2016). Children's posture, stillness and noise output are all subject to teacher attention (Comber, 2004). In addition, how children are understood to be literate, or not, often has implications for where they might be seated, who they 
In: Oakley, G. (2019). Mobile technologies in children's language and literacy: Innovative pedagogy in preschool and primary education. London: Emerald.

might have access to, and what resources they are encouraged or even mandated to use. This may not be surprising as we know that teachers are encouraged to group and differentiate instruction accordingly. When, how, and with what tools children can communicate in schools is also highly regulated. Their own voices, writing and drawing implements, mobile phones and other digital technologies for producing texts are all subject to regulated access and typically under strict adult control (Kuby \& Gutschall Rucker, 2016).

Critical literacy in early childhood classrooms can be understood as incorporating at least three major forms of practice - repositioning students as researchers of language, respecting minority language practices and problematising texts (Comber, 1994), which contest the usual regulation of young children in schools. In the cases which follow we particularly see instances of children being re-positioned as researchers of language and how this can work to alter school socio-material relations. Significantly, the children are not only repositioned in the investigatory aspects of critical literacy concerning language use, but also with this repositioning they have more license to participate in different spaces in the school. This combination of repositionings of young learners, materially, academically and by placing the means of multimodal text production into their hands is potentially a major shift in the power economies of schooling. More recently, literacy researchers have recognised the need to study what is going on beyond literacy events and practices in order to more fully conceptualise diverse learner identities and trajectories. In the chapter, we explore how departures from the ordinary organisation of children's bodies, technologies and school spaces can productively shake up what constitutes early literacy development and force us to attend to difference, power and literatre repertoires.

The communities in which we research, in a range of poor and working class Australian locations are a constant reminder that access to technologies is not equitable. Many households do not have computers, iPads, tablets or computer games. Access to technology through smart phones - which we know has made technology cheaper and more accessible now than in previous decades - has provided some alleviation to this equity gap. However, while we recognise that the affordability of information and communication technologies through smart phones and other devices is resulting in more young children having increasing access to a range of technologies to play, communicate and produce multimodal texts of various kinds (Danby, Davidson, Theobald, Houen \& Thorpe, 2017; Kervin, 2016; Wohlwend, 2008), access to quality in technologies and digital texts is still not equitable. In the long term, schools play an increasingly important role in providing access to technologies for children in poorer communities. And yet for many reasons, including the inability of education systems to provide open free access to online technologies in schools and top-down imperative to push back to the basics, schools have generally been slow to change their practices with regard to students accessing a range of technologies for a range of purposes. Despite this, there are early childhood educators who are willing to experiment with a range of technologies where children come to understand the potential power of text as multimodal producers in school contexts (Kuby \& Gutschall Rucker, 2016; Baroutsis and Towers, 2018; Kervin, Comber \& Woods, 2017; Comber, Woods \& Grant, 2017). In this chapter we draw from the innovative practices of teacher-researchers with whom we are collaborating on a three year study of the ways in which children are learning to produce texts.

\section{Looking for departures}

Our approach has been to foreground the materiality of learning to write, but to also be conscious of social and spatial issues related to children as learners, and to learning. So we have been open to learning new things about who, where, what, with what and with whom children are involved as they become writers. Through this line of thought, the social and material are in a relationship 
In: Oakley, G. (2019). Mobile technologies in children's language and literacy: Innovative pedagogy in preschool and primary education. London: Emerald.

- they are constitutive of everyday life in what Barad (2007) has called intra-action. Fenwick (see for example 2016) reminds us that it is not enough to focus on just the social elements of engaging in everyday practices such as learning to write - rather the social and the material - the human and non-human - are entangled in ways that defy their separation. A sociomaterial approach is cognizant that 'things' or 'stuff' are not just used by humans, rather they must be explored as "effects of heterogeneous relations" (Fenwick \& Edwards, 2011, p. 2).

Kuby, Rucker and Kirchhofer (2015) describe their grappling with the process of using posthuman theory and notions of sociomateriality to analyse data collected in early childhood literacy classrooms in order to find enabling approaches to consider space and materiality of how children learn to write. They settle on an approach to analysis, by focusing on three aspects: "departures from the expected, the notion of becoming, and intra-activity" (p. 403). Taking forward some of their thinking here, we aim to take a sociomaterial approach to understanding the opportunities that are opened when teachers and children intentionally shift authority and control of literacy learning toward children, and when children use learning spaces differently.

We use two examples to represent what can happen when there is a departure from the norm. Many years of experience in schools observing and participating in literacy lessons has provided us with intricate understandings of the macro, meso and micro ways of teaching and learning literacy. So each of these examples demonstrates teachers and children practicing 'learning to write' in ways that were unexpected. The children experienced space differently and indeed experienced or filled different spaces. As children moved fluidly within and between spaces there were unexpected decisions made by children on what to focus on, specifically, what elements to include in the texts they produced.

We were also interested in what these instances of critical literacy pedagogy enabled for the young children involved in terms of the literacy learners they were and were to become. By this we mean that we were able to focus on the new ways of being that the children involved took on. The notion of becoming allowed us to observe how the children involved took up and engaged with materials, how they used the time provided to them to take charge, and how they moved through spaces to get their work done (Kuby, Rucker and Kirchhofer, 2015). Finally, as with Kuby and her colleagues, we have allowed the idea of intra-action to shift our minds to thinking not about children as learners, nor about mobile technologies as tools to support this learning - but instead to consider the in-between entanglements of human child with material resources. This has enabled a focus on the child and technology, moving through physical and virtual spaces, to produce texts. Taking these theoretical ideas forward, we move in the next section to detail two recent examples of young children where technology is used to mobilise critical literacy in their schools.

\section{Two examples of children, mobility and technology for literacy learning}

The data discussed in this paper was collected as part of a larger federally funded, Australian study where teachers, researchers and children have worked together to understand how the teaching of writing is enacted across schools at this time. The project - Learning to write in the early years (LWEYs) ${ }^{1}$ was conducted in two state funded primary schools in communities of

${ }^{1}$ The Learning to write in the early years project team includes Annette Woods, Barbara Comber, Lisa Kervin, and Aspa Baroutsis. We acknowledge the Australian Research Council for funding through its Discovery Program (DP150101240). We wish to thank the leaders, teachers, children, their families and communities who are our research partners and acknowledge their time effort and intellectual input into our work. 
In: Oakley, G. (2019). Mobile technologies in children's language and literacy: Innovative pedagogy in preschool and primary education. London: Emerald.

high poverty. Our overall objective was to consider with teachers and children, what learning to write in contemporary political, policy and education contexts could be. Our emphasis was to investigate high quality, high equity literacy education and how this might be achieved for all children in schools and classrooms. We have worked with teachers to consider learning to write as a collaborative, collective practice, and as a multimodal task where the aim should always be text production and meaning making. The study was conducted in three parts: a school audit where we collected data and reported findings to each individual school; design-based experiments where teachers and researchers worked together to renew and reform the teaching of writing in their classrooms; and case studies of children as they engage in learning to write in their classrooms and schools. In this chapter we draw on data collected as part of two designbased experiments, conducted by teachers in two schools. Design-based classroom experiments enable a better understanding of the learning environment as teachers identify and plan a pedagogical intervention to better support learning (Cobb, Confrey, diSessa, Lehrer \& Schauble, 2003). Design based experiments are framed by the notion that 'systematic and disciplined inquiry into real problems in authentic classrooms is vital to developing workable solutions to support teachers if they are to implement instructional practices that benefit children' (Bradley \& Reinking, 2011, p. 305). Importantly, when researchers and teachers work collaboratively on authentic classroom inquiries they 'close the gap between research and practice' (Bradley \& Reinking, 2011, p. 306) as well as providing teacher professional learning that works towards improving 'teachers' instructional practice and transforming classroom environment' (Bradley \& Reinking, 2011, p. 309).

Both of the schools featured in this chapter are located in Australian communities of high poverty. The first is part of the suburban sprawl of a state capital city. The community has high levels of unemployment and under-employment. The school is surrounded by other schools, but numbers are steadily increasing. There are currently just over 500 students from foundation year to year 6, 10-12\% of whom identify as Aboriginal and/or Torres Strait Islander people. More than $50 \%$ of attending students have a language background other than English with many receiving English as Additional Language/Dialect (EALD) Support, and the school publicly positions itself as multicultural and catering for the needs of diverse cultural groups harmoniously. The second school is smaller, with 200 students, and approximately $12-15 \%$ of those students identifying as Aboriginal and/or Torres Strait Islander people. The number of children accessing support for English language is approximately $10 \%$ of the student cohort. The neighbourhood, once prosperous, has been hit by unemployment and transience with local industry closure. Student numbers at the school are decreasing, and the school finds itself competing with other schools in the area for student numbers. Despite these statistics of disadvantage, both schools have had success and the teachers have continued to focus on pedagogy and curriculum reform over many years and they were eager to participate in the LWEYs project as part of this ongoing work. As with most schools such as these, staff focus has been directed toward improving student outcomes on national tests, with some evidence of improvement at both schools over the past few years.

In the sections that follow we present details of our work with two teachers and several cohorts of children. The first case details children becoming writers in a writing club, an elective activity for children from year 3 and year 5, which was conducted in lunchtime through to the end of the school day, once a fortnight for each of the year levels. The second case details children operating within a classroom unit of study to forge an opportunity to take a mobile device to the office to document the activities of office staff. Pseudonyms are used for all participants in our presentation of these cases. As we examine each case, we ask the question: What happens when children leave their classrooms and are allowed some choice about how bodies, materials and tools move and are used, and how texts are produced and consumed? We 
In: Oakley, G. (2019). Mobile technologies in children's language and literacy: Innovative pedagogy in preschool and primary education. London: Emerald.

are interested particularly in how children represent these experiences using digital or multimodal texts, and the place of digital technologies in how children engage with representing their worlds.

\section{Example 1: Writer's club}

This case details engagement of a teacher leader - Pam (pseudonym) - whose role at the school was to lead classroom teachers in curriculum and pedagogy reform. Part of the leadership team at the school, she also had responsibility for improving outcomes in literacy and numeracy, especially as measured by national literacy and numeracy tests ${ }^{2}$. As such, one component of her role included working with groups of children or individual children, usually with a specific focus on literacy and numeracy. The school, and specifically Pam, had recently started to look closely at a more diverse range of data related to children's literacy outcomes and as a result there was a push to provide access to time to work with Pam to a broader range of children. As such, in a departure from normal practice, from how things had occurred in the past, the idea for the Writers' Club for writers in year 3 and 5 was initiated.

Writers' Club was an outside classroom literacy learning space where children attended on a fortnightly basis - year 3 children one week, year 5 children the next. Pam and the classroom teachers discussed who should be invited, identifying those children who had potential to be strong writers. The teachers recommended some children, and Pam identified others from assessment data - but each child invited to join was determined through a process of negotiation between Pam and classroom teachers before an invitation was issued. The selected children were provided with the choice to attend or not - the sessions went over a lunch time as well as afternoon class time so the children had to be willing to be involved during their free time. All the children who received an invitation agreed to become members. One additional year 4 child came to the Club uninvited, and managed to negotiate her inclusion with Pam, such was her enthusiasm for writing.

There was a general level of excitement during each Club session, lots of talking, lots of writing, and lots of laughter. All Club members were provided with a folder and writing materials. They were told why they had been selected, and their responsibilities were identified including the responsibility of care for the new Club folders. The purpose of the Club was expressed as having two dimensions. First, to support members to become better writers, and secondly, for the members to become leaders of writing in their classrooms. The first weeks of Writers' Club engaged the first purpose. Children wrote in their folders, they were involved in mini lessons about sizzling starts for writing. They settled into a practice of writing a newsletter entry to tell their parents, teachers and friends about what they were doing in the Club. This activity was usually completed by a small group with the researcher. In the first few weeks, all Club members participated in an external writing competition, and almost all received the wonderful news that their texts would be published in a yearbook. The children wrote as much between Club sessions as they did during the sessions, and often came to Club to have the adults who attended read their written texts.

The club struggled to find a home - a space that could be usefully used for purpose. They began in Pam's Office, but often struggled to find places to sit, to work together or with adults, or to see computers or texts being modeled. The small space seemed to amplify noise. They moved

\footnotetext{
${ }^{2}$ In Australia in 2018 all children in years 3, 5, 7, and 9 sit national tests in literacy and numeracy. The National Assessment Program in Literacy and Numeracy (NAPLAN) involves all Australian children being tested across five domains - reading, writing, spelling, punctuation and grammar, and numeracy - in tests held each May.
} 
In: Oakley, G. (2019). Mobile technologies in children's language and literacy: Innovative pedagogy in preschool and primary education. London: Emerald.

to another classroom which housed a variety of intervention programs and staff. This space worked well during the lunch time, but interfered with other activities during the afternoon class time. So they returned to the rather cramped office space, making do with sharing chairs or finding floor space to write and talk. Pam and the children talked about this use of space and what would work best - the decision to return to the Office was made collectively. The children were part of the decision-making process about where to meet. This issue alerts us to the politics of space within schools; it is not simple for teachers and students to find places to write together at times which have not been time-tabled, such is the specific designation of people, technologies, furniture and resources. This challenge makes us attend to the sociomateriality of everyday literatre practices in schools. Disruption to the usual routines produces more work for Pam, as she advocates for the children to actively support their peers in writing.

The children had access to additional materials and had some control over how they worked and where, interactions between children and adults were informal although focused on the task at hand - writing and producing texts. However, for the most part the Writers' Club engaged children in writing as they might in many classrooms where independent writing or process writing is the approach taken. What we are interested in for this chapter is when Pam and the children shifted the purpose Club membership from being a writer to being an advocate - $a$ supporter of others and their writing.

This move was deliberate on the part of Pam and it marked several other shifts in the material, spatial, and relational practices of what 'being' a Club member involved. After being told of the shift, the children were asked what their first move might be. An active discussion ensued - resulting in a decision that they should produce messages and texts that would encourage other children to write. They then asked the adults in the room to help with how this could be accomplished, with each of us suggesting something where we had some expertise to offer. The choice toward microphotography was no doubt driven by the promise of access to digital tools. The children were handed iPads and left the Office space to find inspiration. After a short tutorial from one of the researchers on different techniques and effects possible, the children ran, holding iPads close to their chests, stopping to look closely and then capture surprising images. They often returned to one of the adults to show the effects they had produced, suggesting how they might use the photo. They discussed locks and unlocking writing and ideas, looking into other worlds as they took close shots of drains and metal fencing, looked up and down with their camera's capturing the different perspectives, engaged human bodies with materials and texts already available such as murals on walls, fences and trees and plants. Some focused their ideas on particular groups of students who they perceived might need more support, for example some girls found the word 'boy' wherever possible and photographed many different versions - this they explained would mean they could create a stimulus specifically for the boys in their class who they said were having trouble learning to write. The point is, that removed from the constraints of a classroom space, these children and their iPads captured and recorded different perspectives of the place they called school. Children had become other than students, they decided where to go and what to do - their roles had shifted and they were in charge of making some decisions. They looked through the digital technology and recorded different versions of the world - the in-between, as human and non-human worked together to produce different views and perspectives.

On returning to the Office, the children worked with Pam and each other on desktop and laptop computers, with paper and pencils to produce their posters and stimulus posters. Words, images, effects coming together to make meanings that had not existed before this process, that neither resided with the children, the adults or the technologies or tools. The texts produced were the result of what Lenz Taguchi (2010) discusses as the intra-active relationship between human, non-human, materials, and we would add spaces. 
In: Oakley, G. (2019). Mobile technologies in children's language and literacy: Innovative pedagogy in preschool and primary education. London: Emerald.

Eventually the posters were produced and laminated for use around the school grounds and in classrooms. But the children continued to take their role as writing advocates to mean they could continue to drive the process of supporting others to want to write. With a great deal of support from Pam, the children produced writing tubs for each class, seeming to understand the privilege of access to materials to produce texts. The Club members were involved in naming these packs - Motivation to Write tubs - and several children presented their imminent arrival in 'a classroom near you' on the school parade. The impact of these activities on the school more broadly remains to be seen - but regardless it is worth noting how young children can be involved in their own and others' learning and the potential of allowing children to move, to engage space and materials, and to take authoritative roles where decisions are made collectively and materials and people come together.

\section{Example 2: Children using mobile technologies to become researchers and producers}

While in the previous example, we see the school leader's office was used as a meeting room for the Club, some school spaces are reserved for the important adults who 'run' the school as an institution - particularly the leadership team and the administrative staff. For instance, the principal and assistant principals' office, as well as the spaces behind the counter in the foyer staffed by administrative colleagues are almost always reserved for adults. Children usually only enter such spaces when something is amiss (illness or inappropriate behaviour) or being privileged to take a message from a teacher or to be rewarded for something exceptional.

This next example comes from a Year 1/2 composite class. The teacher - Simon (pseudonym) - was in his third year of teaching (his second year at this school) and the children were aged between 6 to 8 years and in their second or third years of school. This classroom was in the block furthest from the office area; the office area and the classroom were connected by a winding pathway past another three classroom blocks and more than 50 steps to access the tiered buildings on quite a steep block of land. Neither area was visible to the other.

In this example, Simon encouraged the children to become researchers and digital text producers. During a unit of study on "communication" the children engaged with a photo study of historical communication forms and examined different strategies for communication (including telephones and telegrams through to computer-based technologies). The unit of work then addressed communication strategies in different locations within their school. Initial discussions were focused on typical interaction patterns between the teacher and children in the classroom, before considering what communication strategies were like in different locations in the school (such as the school canteen, during assemblies, at the recent school disco and eventually the office building). After whole class discussion, Simon invited the children to capture their insights into communication strategies within the school; the children worked in pairs to write, draw or create multimodal digital representations of their understandings.

In this example, two children (Sam and Catherine, pseudonyms) chose the office as a location, sought permission from their teacher to access the space, and then directed and captured photographs on a class iPad as they talked with their participants (two office staff - the office manager and office assistant) for 19 minutes about how they communicate with others. As Sam and Catherine asked questions of their participants in the office space they made decisions about what images to capture on the iPad. They directed the office staff to pose for photographs as they highlighted their use of communication tools within the office space. Using the technique of a Digital Story (Kervin \& Mantei, 2016), the children used the still images they captured and narrated these into a cohesive account of communication in their selected space. They reviewed and sequenced their images as they decided what to record for their oral narration. Further, as 
they edited images and audio together on the iPad, they also composed written annotations to further emphasise their meaning.

In this 1 minute and 5 second Digital Story, these two seven year old children collaborated to capture their experience of interviewing the office manager and office assistant in the School Office within their school. In this example we see the potential of positioning students as researchers of everyday places and practices. We also see what can happen when the means of production are in children's hands. Table 1 provides an overview of the time sequence within the digital story and the oral narration, written annotation and description of the image that accompanied each section.

Through the authority of this literacy activity, the children were able to visit a space they were typically not allowed to go - the school office. Here we see a shift in the equilibrium of the power relations, between child in the role of 'the student' and the adult in the role of 'the office staff'. Further, they not only visited but also asked questions and documented their experience through planning and capturing photographs where they were able to manipulate the adults who inhabited the space (through their staging of photographs and providing written annotations to capture their intention in creating the image and their own interpretations). The mobile device they took with them, positioned these children as researchers and thereby made it allowable for them to ask the office staff to pose for photographs and provide information, and simultaneously enabling these children to document their learning experiences. The children were in control of the experience. We see adult bodies directed by the young text producers. This example disrupts established adult child-relationships in this office space as the human participants and the nonhuman (communication resources) are entangled in ways that are directed by the young children to facilitate their literacy learning. 
In: Oakley, G. (2019). Mobile technologies in children's language and literacy: Innovative pedagogy in preschool and primary education. London: Emerald.

Table 1: overview of time, oral narration, written annotation and image within the digital story

\begin{tabular}{|c|c|c|c|}
\hline $\begin{array}{c}\text { Time } \\
\text { sequence }\end{array}$ & Oral narration & Written annotation & Image description \\
\hline $00: 00-00: 10$ & $\begin{array}{l}\text { Sam: Hi I'm Sam } \\
\text { Catherine: And I'm } \\
\text { Catherine } \\
\text { Sam:We went to the } \\
\text { office to see ways we } \\
\text { can communicate. }\end{array}$ & $\begin{array}{l}\text { Sam and Catherine } \\
\text { investigate How to } \\
\text { Communicate in the } \\
\text { Office }\end{array}$ & $\begin{array}{l}\text { Photograph of Sam and } \\
\text { Catherine in front of a brick wall } \\
\text { near the office block. }\end{array}$ \\
\hline 00:11-00:17 & $\begin{array}{l}\text { Catherine: When people } \\
\text { come to our school they } \\
\text { go to the desk to ask } \\
\text { questions. }\end{array}$ & Ask and answer questions & $\begin{array}{l}\text { Photograph of smiling office } \\
\text { manager standing behind from } \\
\text { counter }\end{array}$ \\
\hline $00: 18-00: 24$ & $\begin{array}{l}\text { Sam: When the office } \\
\text { wants to send out } \\
\text { information they use a } \\
\text { letter. }\end{array}$ & Send letters & $\begin{array}{l}\text { Close photograph of the office } \\
\text { manager's hands holding an } \\
\text { envelope and note slip, both } \\
\text { featuring the school emblem and } \\
\text { contact details. }\end{array}$ \\
\hline 00:25-00:39 & $\begin{array}{l}\text { Catherine: Sometimes } \\
\text { the office asks parents } \\
\text { questions. Sometimes } \\
\text { parents ask the offices } \\
\text { questions. }\end{array}$ & Talk on the phone & $\begin{array}{l}\text { Photograph of the office } \\
\text { assistant holding the phone to } \\
\text { her ear, smiling at the camera. }\end{array}$ \\
\hline 00:40-00:49 & $\begin{array}{l}\text { Sam: Sometimes the } \\
\text { school emails the } \\
\text { parents and sometimes } \\
\text { the parents email the } \\
\text { school. }\end{array}$ & Use the computer & $\begin{array}{l}\text { Photograph of the office } \\
\text { assistant pretending to work on } \\
\text { the desk top computer, side view } \\
\text { to the camera. }\end{array}$ \\
\hline 00:50-00:56 & $\begin{array}{l}\text { Catherine: If there's a } \\
\text { message the whole } \\
\text { school needs to hear } \\
\text { they do it on the } \\
\text { loudspeaker. }\end{array}$ & $\begin{array}{l}\text { Talking into the } \\
\text { loudspeaker }\end{array}$ & $\begin{array}{l}\text { Photograph of the office } \\
\text { assistant pretending to speak into } \\
\text { the microphone on top of a filing } \\
\text { cabinet, side view to the camera. }\end{array}$ \\
\hline 00:57 & $\begin{array}{l}\text { Sam: The people in the } \\
\text { office are very, very, } \\
\text { very busy } \\
\text { Catherine: and have to } \\
\text { communicate with } \\
\text { heaps of people. }\end{array}$ & The end & $\begin{array}{l}\text { Blurred photograph of office } \\
\text { assistant standing behind the } \\
\text { front counter. }\end{array}$ \\
\hline
\end{tabular}


In: Oakley, G. (2019). Mobile technologies in children's language and literacy: Innovative pedagogy in preschool and primary education. London: Emerald.

\section{Discussion}

These two cases demonstrate children reinterpreting school spaces through their creation of digital texts. In both cases the children, as co-researchers, were engaged in meaningful and sustained literacy learning as they moved across school spaces not always available to students for literacy learning work. These critical literacy practices pose implications for all educators as to how literacy and critical literacy can be taught to young children when they are afforded some control of decisions about how, where and when people, materials, tools and texts are used. In particular these cases encourage us as educators to examine how children might be readers, writers and analysts and in so being, how they might resist traditional roles, positions and placements in their literacy learning. Further we think there is more to be done to consider how mobile technologies might support children to produce texts that challenge understandings of learning spaces. Rather than early literacy constuting training in the management of students' bodies and their quiet confinement to limited places and activities, early critical literacy could be re-imagined as active, collaborative, mobile and public.

These cases demonstrate teaching and learning approaches to critical literacy that position the children as researchers, producers, and teachers, In each case they were learning literacy in spaces outside the traditional classroom and were given opportunities to challenge and shift the relationships between themselves, materials and adult experts. The children assumed tech-savvy roles (Vasquez \& Felderman, 2013) as they used technology to become leaders, photographers, interviewers and authors. In each instance the children were asked to problematise and challenge who, how, where, when, with what and with whom things like producing text get done in schools.

Mobile technologies in children's hands potentially shifts the socio-spatial power relations around text production that usually hold in schools. In these cases, the children used technology to create artefacts that reflected their mindsets, identities and literate practices (Kuby \& Gutshall Rucker, 2016; Vasquez \& Felderman, 2013). In those moments, supported by teacher-researcher advocates, the children took control of the technology to reshape their response to curriculum. Their activation of their "technoliteracies" (Marsh, 2002) enabled them to produce texts to support their learning and rearticulation/redefinition of the types of learning that occurs within school spaces. These instances indicate what is can be possible when young children and teachers work in different relationships with materials, spaces and other people in productive and provocative ways. Children's capacities to co-produce multimodal texts of various kinds are contingent upon the extent to which the school opens its spaces and resources, both material and human, to afford children ongoing access in order to meet genuine demands of learning together. We recognize that such innovation requires long-term hard work and commitment on the part of classroom teachers and school leaders, and this all the more pressing at a time when minimalist approaches to early literacy instruction are constantly portrayed in the media and frequently by political leaders as a solution to the low levels of performance on literacy standardized tests. Children as co-researchers with their teachers enables spaces and literacy opportunities to be transformed. Further, with the incorporation of mobile technologies, we argue critical literacies have the potential to become truly mobilised as children actively participate with the 'business' of literacy learning. 
In: Oakley, G. (2019). Mobile technologies in children's language and literacy: Innovative pedagogy in preschool and primary education. London: Emerald.

\section{References}

Baroutsis, A. \& Towers, C (2017). Makerspaces: Inspiring writing in young children. Practical Literacy: The Early and Primary Years, 22(3), 32-34

Bradley, B.A. \& Reinking, D. (2011). Enhancing research and practice in early childhood through formative and design experiments. Early Child Development and Care, 181(3), 305-319.

Cobb, P., Confrey, J., diSessa, A., Lehrer, R. \& Schauble, L. (2003). Design experiments in educational research. Educational Researcher, 32(1), 9-13.

Comber, B. (2000). What really counts in early literacy lessons, Language Arts, 78(1),39-49.

Comber, B. (2004). Three little boys and their literacy trajectories. The Australian Journal of Language and Literacy, 27(2), 114-127.

Comber, B. (1994). Critical literacy: an introduction to Australian debates and perspectives, Journal of Curriculum Studies 26(6), 655-668.

Comber, B., Woods, A. \& Grant, H. (2017). Literacy and imagination: Finding space in a crowded curriculum. The Reading Teacher, 71(1), 115-120. doi: 10.1002/trtr.1539

Danby, S., Davidson, C, Theobald, M, Houen, , \& Thorpe, K. (2017). Pretend play and technology: Young children making sense of their everyday social worlds. In S. Lynch, D. Pike, \& C. à Beckett, (Eds.) Multidisciplinary Perspectives on Play from Birth and Beyond (pp. 231-245). Singapore: Springer Singapore, Singapore.

Dixon, K. (2011). Literacy, power, and the schooled body: Learning in time and space. New York, NY: Routledge.

Dyson, A. H. (Ed.). (2016). Child Cultures, Schooling and Literacy: Global Perspectives on Children Composing Their Lives. New York \& London: Routledge.

Fenwick, T. (2016) Social media, professionalism and higher education: a sociomaterial consideration. Studies in Higher Education, 41 (4), pp. 664-677.

Fenwick, T., \& Edwards, R. (2011). Considering materiality in educational policy: Messy objects and multiple reals. Educational Theory, 61(6), 709-726.

Kamler, Barbara, Maclean, Rod, Reid, Jo-Anne and Simpson, Alyson (1994) Shaping Up Nicely: The Formation of Schoolgirls and Schoolboys in the First Month of School. Australian Government Printing Service, Canberra.

Kervin, L. (2016). Powerful and playful literacy learning with digital technologies. Australian Journal of Language and Literacy, 39 (1), 64-73.

Kervin, L., Comber, B. \& Woods, A. (2017). Toward a Sociomaterial Understanding of Writing Experiences Incorporating Digital Technology in an Early Childhood Classroom. Literacy Research: Theory, Method, and Practice Vol. XX, 1-15 DOI: $10.1177 / 2381336917718522$

Kervin, L. \& Mantei, J. (2016). Digital storytelling: capturing children's participation in preschool activities. Issues in Educational Research, 26 (2), 225-240.

Kuby, C. \& Gutshall Rucker, T. (2016). Go be a writer! Expanding the curricular boundaries of literacy learning with children. New York: Teachers College Press.

Kuby, C., Rucker, T. \& Kirchhofer, J. (2015). 'Go Be a Writer': Intra-activity with materials, time and space in literacy learning. Journal of Early Childhood Literacy, 15(3), 394-419

Luke, A. (1992). The body literate: Discourse and inscription in early literacy training. Linguistics and Education, https://doi.org/10.1016/0898-5898(92)90021-N

Marsh, J. (2016). In Dyson (Ed.). The situated cases: Child agency, cultural resources, language, Child Cultures, Schooling, and Literacy: Global Perspectives on Composing Unique Lives (pp. 15-115). 
In: Oakley, G. (2019). Mobile technologies in children's language and literacy: Innovative pedagogy in preschool and primary education. London: Emerald.

Vasquez, V. M. (2014). Negotiating Critical Literacies with Young Children (10th Anniversary Edition). New York: Routledge.

Vasquez, V. M. \& Felderman, C. B. (2013). Technology and Critical Literacy in Early Childhood. New York: Routledge.

Wohlwend, K. (2008). Play as a literacy of possibilities: Expanding meaning in practices, materials and spaces. Language Arts, 86(2), 127-136.

Woods, A. and Henderson, R. 2008. The early intervention solution: Enabling or constraining literacy learning. Journal of Early Childhood Literacy, 8, 268-276. 